\title{
PLANS FOR THE EDUCATION OF DISABLED AND CON- VALESCENT OFFICERS OF BRITISH AND ALLIED FORCES
}

By Henry Chellew, D.Sc., Honorary Secretary, London School for Officers

In order that wounded officers of the English and Allied Armies may have the opportunity to receive educational or technical training during the time of their convalescence, classes for this purpose have been instituted by the Appointments Department, Ministry of Labor, London. In these classes, opportunity is afforded these officers for such educational or technical training as will fit them for munitions or other national war service so long as the medical board certifies them as unfit for general service. Further, they will be fitted for their eventual re-entry into professional, scientific or commercial occupation with new knowledge, completed training and refreshed experience.

The purposes of the officers' university and technical classes ${ }^{1}$ are as follows:

1. The restoration of the health of wounded and debilitated officers, so that if possible they may be restored to general service fitness.

2. Alternatively the provision of technically trained officers who, after a course of instruction, remaining unfit for general service, are available for Ministry of Munitions or other national requirements.

But in addition there is the broad purpose of:

3. The building up of the scientific and technical knowledge of the nation.

4. The provision of a system by which the officer proving to be unfit may be guided toward resettlement in civil life through a process based on training.

The Department is staffed almost entirely by serving officers who are temporarily disabled. Headquarters and each district directorate is a training field in business administration. Selections

${ }^{1}$ It should be noted that the London Officers' University and Technical Classes is in liason with the University of London and with all the colleges, institutions and polytechnics of the University, besides many institutions and private coach. ing firms which do not come under the jurisdiction of the University. 
are made from the officers for attachment to such offices, and important emergency calls to appointments are filled from time to time direct from among the tested members of these staffs. Others are then brought forward for training.

\section{Opportunity for Future Career}

Endeavour is made to place a man according to the indication which a consideration of the future career of each candidate suggests as most advisable. So it is that arrangements are being made with each University by which the time spent at the University studying one or another subject may count towards a degree, provided the officer-student after the war, or when released from the army, decides to return to the University to continue his studies and pass the necessary matriculation or other examinations if he has not already done so. The Universities are giving to each officer-student, if he leaves, a simple certificate setting forth the time which the officer has spent at the University, the subject upon which he has been engaged, and so far as possible the quality of the knowledge he has attained.

It will be seen that the scheme of the Appointments Department, under the system as carried out through the officers' classes, gives opportunity for study at the earliest possible moment to every officer so seriously damaged or debilitated as to have six months inactivity ahead of him when last Boarded. It gives the government offices and private firms the opportunity of selecting from such officers the men they require. It gives the officer a better chance of recovery to fighting fitness. It gives the too seriously damaged officer the hope of passing out to civil life without jar and with mental activities operating. Further, it gives to the officers of the Ministry of Pensions, who are working in close coöperation with the officers' classes, a review of each seriously damaged exofficer, a review prepared not in a moment, but based on a record created by the officer himself while attached as a serving officer to an adjutant who is responsible for keeping his district director and headquarters informed as to the studies, successes and difficulties of each officer attached to him.

The serving officer seriously damaged who makes earnest effort while serving and attached to the officers' classes 'may expect the best possible consideration from the officers of the Ministry of Pensions when he in due course becomes an ex-officer.

\section{Courses Open to Discharged Officers}

With a view to assisting discharged officers to fit themselves for suitable appointments in civil life, a course on business education and administration has been arranged by the London School for Officers. The course is not of a theoretical or academic nature, but 
is designed to suit, as far as possible, the special requirements of those who are likely to attend it.

Subject to such alterations as may seem desirable from time to time as the scheme develops, it is proposed that the subjects comprised in the course should be as follows:

1. Accounting: Giving special attention to company accounts, cost accounts, agricultural accounts, and the accounts of foreign traders.

2. Business Organization: Dealing with the varying forms of organization suitable to different types of businesses; the relations of business houses towards each other; the effective control of employes; the handling of work-people; and other similar subjects of especial importance at the present time.

3. Commercial and Industrial Law: Approached from the point of view of the business man, rather than from the point of view of the lawyer.

4. The Elements of Commerce: Including the organization of British and foreign trade, and the organization of markets, economic and geographical. This course will include an explanation of the resources of the various parts of the British Empire, and of the more important foreign countries.

Other business subjects will be arranged for as and when experience suggests the desirability of so doing.

The course will consist of twelve weeks' instruction, given partly by lectures, partly in classes and partly by means of seminars. The first course was started Monday, July 1, 1918, and arrangements made for subsequent courses at intervals of three months. Every effort will be made to let the men attending these classes feel that they are receiving individual attention at the hands of the lecturers who will, so far as lies in their power, assist the officers who have lost touch with business affairs to regain confidence in themselves and in their ability to follow a successful business career. It is confidently expected that a large number of business houses will gladly welcome these courses and do their best to provide suitable employment for those who have passed through them. It is proposed that the government should pay towards the cost of maintaining these courses an inclusive fee of $£ 6.6$. Od. (about $\$ 30.00$ ) per officer per quarter, and under present conditions the executive committee could arrange to accommodate one hundred officers simultaneously.

The following subjects are announced by the school for Courses I and II: 
CoUrse I

\author{
Industrial Economics and Psychology
}

The Science of Industry and Commerce: The Sources of Efficiency: Functional Management: The Problem of Supervision: Direction and Control: The Human Factor: Industrial Pyschology: The Problem of Discipline: Time, Energy, and Money: Handling and Training the Staff: Marketing the Product: Post-War Problems in Commerce.

\title{
Business Organization and Administration
}

General Introduction: The Constitution of Business Houses: Partnerships: Companies: Ententes and Alliances of $(a)$ Men (b) Masters: Business Terms and Their Meanings: Business Finance: Capital and Revenue: The Organization of Credit and Paymenta: Bills of Exchange: Cheques: The Stock Exchange: Secretarial Work: Meetings, Reports, Agenda, and Minutes.

\section{Commercial Law}

Sale of Goods: Nature of Business Contracts: Who May Contract: What Constitutes Offer and Acceptance: Void and Voidable Contracts: Bankruptcy and Bills of Sale: Master and Servant: Bailment: Carriers.

\section{Accounting and Business Methods}

The Aims of Accounting: The Meaning of an Account: Debit and Credit: The Theory of Double Entry: The Trial Balance: "First Entry" Records: Capital and Revenue: Balance Sheets and Profit and Loss Accounts: The "Double Account" System: Depreciation: Trading Accounts: Stock Accounts: Modern Methods of Accounting without Books: Sectional Balancing.

\section{Commerce and Commercial Geography}

The Exchange of Goods: Markets: Speculation: Prices: Costs of Transport and Marketing: Freight Rates: Prices and Values: Payment for Goods: International Indebtedness.

The geographical distribution and supply within the British Empire of some of the more important food-stuffs and raw materials of Industry, with special reference to the position and needs of the United Kingdom.

\section{CoURSE II}

\section{Industrial Economics and Psychology}

The Science of Organization: The Scientific Method Applied to Industry: Internal Organization: The General Manager and His Functions: The Human Factor in Management: Staff Training: Psychology as Applied to Industry: Methods of Increasing Efficiency: Men, Money and Machinery: Vocational Adaptation: The Nature of Industrial Regimentation: Scientific Distribution.

\section{Business Organization}

The Remuneration of Employes: Credit Records and the Handling of Bad 
Debts: Selling: Advertising: Buying: Cycles of Trade: Speculation in Relation to Business: Hedging: Insurance: The General Organization of Expanding, Contracting, and Temporary Businesses Compared: State Regulation of Trade and Industry.

\section{Banking, Currency and Exchange (6 Lectures)}

The Functions of Money and Types of Money: The Functions of the Banker: Banking Business as Revealed by the Analysis of Banking Balance Sheets: The Bank of England: The Bank Rate: Foreign Exchanges.

\section{General Elementary Methods of Statistics (6 Lectures)}

The Collection of Data: Definition of Units: Classification and Tabulation: Percentages: Averages: Graphic Methods.

\section{Commercial Law}

Principal and Agent: Executorships and Trusts: Bills of Exchange, Bills of Lading, and other negotiable instruments: Persons under Disability: Partnerships: Insurance: Limitations of Actions: Remedies.

\section{Accounting and Business Methods}

Methods of Balancing: Branch Accounts: Foreign Currencies in Accounts: Foreign Branches: Systems of Internal and External Check: Precautions against Fraud: Tabular Bookkeeping: Periodical Returns: Reserves and Reserve Funds: Goodwill: Profits: Partnership Accounts: Capital Reorganizations: Cost Accounts: Criticism of Accounts.

\section{Public Administration}

The Structure, Finance, and Functions of Local Government Bodies in England.

The Commercial Relations of the Chief European Countries before the War

The Geographical Basis of the Internal Trade of Europe: Deficits of Continental Europe Supplied from the Outside World: The Work of British Shipping: Europe as a Market for the United Kingdom: The Coal Trade and Its Importance: The Demand for Manufactures: Competition: Transport and Tariffs: Financing of Industries and Trade: Peaceful Penetration: The Relations of Central Powers with Neighbouring Areas.

Lectures on Various Subjects, by Well-Known Authorities 